\title{
Effects of supplemental xylanase and xylooligosaccharides on production performance and gut health variables of broiler chickens
}

\author{
Amit K. Singh ${ }^{1}$, Birendra Mishra', Michael R. Bedford ${ }^{2}$ and Rajesh Jha ${ }^{1 *}$ (D)
}

\begin{abstract}
Background: This study evaluated the effects of supplemental xylanase and xylooligosaccharides (XOS) in a cornsoybean meal (SBM)-based diet on growth performance and intestinal health of broilers. A total of 288 day-old chicks (Cobb 500) were allocated to 36 floor pens ( 8 birds/pen) equally in 9 dietary treatments in a $3 \times 3$ factorial arrangement. The treatments were combinations of 3 levels of xylanase $(0,0.005 \%$ and $0.01 \%$ Econase XT) and 3 levels of prebiotics $(0,0.005 \%$ and $0.01 \%$ XOS) added to basal mash diets formulated in three phases (starter, $\mathrm{d} 0$ 14; grower, d 15-28; finisher, d 29-42). The feed intake and body weights were recorded weekly. On d 42, ileal sections were collected for histomorphometric and gene expression analysis, and cecal content was collected for determining short-chain fatty acids (SCFA) and microbiota.
\end{abstract}

Results: Xylanase linearly $(P<0.01)$ increased the average daily gain $(A D G)$ in both the finisher and total period and the final body weight gain (FBWG, 2940 \& 2932 vs. 2760 g) of broilers. XOS did not significantly increase either ADG or FBWG $(P>0.05)$. Supplemental xylanase and XOS did not affect average daily feed intake and feed conversion ratio $(P>0.05)$. Xylanase and XOS did not change villus height $(\mathrm{VH})$ or crypt depth $(\mathrm{CD})$ ratio $(P>0.05)$. However, xylanase exhibited a trend $(P=0.097)$ on $\mathrm{VH}: \mathrm{CD}$ ratio. The inclusion of $0.01 \%$ XOS without xylanase increased the level of IL-10 (a marker of anti-inflammatory cytokine) and IL-4 (a T-cell differentiation cytokine) genes compared with control $(P<0.05)$. The acetate production was increased by xylanase $(P<0.01)$ and $\mathrm{XOS}(P<0.05)$ without an additive effect. Xylanase increased total SCFA $(P<0.01)$ while XOS had a tendency to increase $(P=0.052)$. Alpha and beta diversity of microbiota among treatments were not different $(P>0.05)$. However, the mean proportion of family Ruminococcaceae was increased by the supplemental $0.01 \%$ xylanase $(P<0.01)$.

Conclusion: It can be concluded that XOS can enhance cecal fermentation, while xylanase can increase the body weight gain along with the fermentation metabolites in the ceca of broilers fed the corn-SBM-based diet but the effects may not always translate into an improved mucosal absorptive capacity and a better feed efficiency.

Keywords: Gene expression, Histomorphology, Microbiota, Poultry, Prebiotics, Short-chain fatty acid, Xylooligosaccharide

\footnotetext{
* Correspondence: riha@hawaii.edu

'Department of Human Nutrition, Food and Animal Sciences, University of Hawaii at Manoa, Honolulu, HI 96822, USA

Full list of author information is available at the end of the article
}

C C The Author(s). 2021 Open Access This article is licensed under a Creative Commons Attribution 4.0 International License, which permits use, sharing, adaptation, distribution and reproduction in any medium or format, as long as you give appropriate credit to the original author(s) and the source, provide a link to the Creative Commons licence, and indicate if changes were made. The images or other third party material in this article are included in the article's Creative Commons licence, unless indicated otherwise in a credit line to the material. If material is not included in the article's Creative Commons licence and your intended use is not permitted by statutory regulation or exceeds the permitted use, you will need to obtain permission directly from the copyright holder. To view a copy of this licence, visit http://creativecommons.org/licenses/by/4.0/ The Creative Commons Public Domain Dedication waiver (http://creativecommons.org/publicdomain/zero/1.0/) applies to the data made available in this article, unless otherwise stated in a credit line to the data. 


\section{Introduction}

The application of exogenous enzymes in fibrous diets has been found to increase nutrient utilization and subsequently improve the growth performance of broilers $[1,2]$. However, the response of different enzymes is not consistent, and it could vary based on the types of ingredients present in the diet. Among the exogenous enzymes, xylanase is commonly used to improve nonstarch polysaccharide (NSP) degradation in wheat-based diets, but it is also increasingly being used in corn-based diets in broilers $[3,4]$. The enhancement in digestibility and the improvement in nutrient utilization are essential for the improved growth performance. For better nutrient utilization, proper functioning of the immune system and overall good gut health are essential in broilers. To ensure improved nutrient utilization, it requires an increased mucosal surface area for absorption, a better access of digestive enzymes to nutrients in the digesta, and increased NSP degradation in the host [5]. Exogenous enzymes like xylanase could reduce the intestinal digesta viscosity, enhance the absorption of nutrients and concurrently increase the rapidly fermentable substrates for the normal gut microbiota [6].

Feeding xylanase increases the contents of xylooligosaccharides (XOS) and xylose in the colon and ceca through the hydrolysis of polymeric xylans and influences the cecal microbiome to increase the fermentation metabolites [7-9]. The short-chain oligosaccharides provide substrates to establish the commensal microbiome in the lower gut $[10,11]$. Xylanase has been reported to increase Lactobacillus spp. counts in the intestine, reduce gram-positive cocci and enterobacteria, and increase the production of butyrate in broilers [12]. In addition to the improvement by xylanase, prebiotics can also influence the health and growth performance of broilers by modulating and supporting the growth of beneficial intestinal microbiota [13]. Prebiotics can stimulate immunity either directly or through the fermentation metabolites produced in response to the enhanced colonization of GIT by beneficial microbiota [5]. Besides other oligosaccharides, XOS is being studied as a potential prebiotic since it had been shown to promote the production of butyrate by cross-feeding of lactate to butyrate-producing bacteria and support the intestinal mucosa of broilers [14]. Moreover, XOS supplementation increases short-chain fatty acids (SCFA), stimulates the immune system, and increases the population of beneficial bacteria in chickens $[15,16]$. Increased production of fermentation metabolites like SCFA can enhance the growth of intestinal villi and improve mucosal health. Besides supporting the gut microbiome, XOS is also reported to enhance the immune response by maintaining antibody titers, boost endocrine metabolism, and improve growth performance [17].
However, further studies are necessary to ascertain the roles of xylanase and XOS in improving immune response, modulating microbiota in the ceca, and enhancing fermentation metabolites in broilers. Moreover, to supplement xylanase and XOS in regular feed production, a thorough evaluation of their interaction effect on the gut health and growth performance of broilers is required for determining their optimum inclusion level. The objective of this study was to investigate the effects of supplementing various levels of xylanase and XOS on growth performance, ileal histomorphology, immune response, cecal fermentation metabolites, and cecal microbiome of broilers.

\section{Materials and methods}

\section{Experimental design and dietary treatments}

A growth performance study in floor pens was conducted at the Small Animal Facility of the University of Hawaii at Manoa. This study was carried out following the approved protocol from the Institutional Animal Care and Use Committee of the University of Hawaii. The diets were formulated with the same basal composition using corn and soybean meal in three phases: starter for d 0-14, grower for d 15-28, and finisher for d 29-42 (Table 1). The nutrient composition of the diets was managed to meet the requirements of broilers [18]. The formulated diets had 3 levels of xylanase enzyme (Econase XT $0 \mathrm{~g} / \mathrm{t}-0$ or no enzyme, Econase XT $50 \mathrm{~g} /$ $\mathrm{t}-0.005 \%$ or $8,000 \mathrm{BXU} / \mathrm{kg}$ Econase XT, and Econase XT $100 \mathrm{~g} / \mathrm{t}-0.01 \%$ or 16,000 BXU/kg Econase XT) and 3 levels of XOS prebiotic (XOS $0 \mathrm{~g} / \mathrm{t}$ or $0 \%$, XOS $50 \mathrm{~g} / \mathrm{t}$ or $0.005 \%$, and XOS $100 \mathrm{~g} / \mathrm{t}$ or $0.01 \%$ ) supplemented in a completely randomized design in $3 \times 3$ factorial arrangement. Thus, the combination of xylanase and XOS produced 9 dietary treatments. Phytase (500 FTU/kg of Quantum blue; AB Vista Feed Ingredients, Marlborough, Wiltshire, UK), with a matrix value of $0.16 \% \mathrm{Ca}$ and $0.15 \% \mathrm{P}$, was added in all diets. The diets were prepared and fed as mash to the birds in all treatment groups.

\section{Experimental methods and housing arrangement}

A total of 288 one-day-old unsexed Cobb 500 broiler chicks were used. All birds were raised in standard broiler rearing environments in floor pens. The chicks were randomly allocated to 36 pens so that each pen had 8 birds, and 4 pens were assigned to each treatment. The feed and water were provided ad libitum to the birds in all pens. The feed intake and the weight of birds were measured weekly from d 0 till $d 42$. The average daily gain (ADG), average daily feed intake (ADFI), and feed conversion ratio (FCR) were calculated from the data for all three phases and total period. The daily mortality was recorded along with feed intake to adjust the FCR for each pen. On d 42, the body weight of the birds 
Table 1 The composition of ingredients and nutrient content of diets supplemented with xylanase and xylooligosachharides and fed in different phases to broiler from d 0-42 (as-fed basis, $\mathrm{g} / \mathrm{kg}$ unless otherwise indicated)

\begin{tabular}{|c|c|c|c|}
\hline & \multicolumn{3}{|c|}{ Inclusion level $^{\mathbf{b}}$} \\
\hline & $\begin{array}{l}\text { Starter } \\
\text { (d 0-14) }\end{array}$ & $\begin{array}{l}\text { Grower } \\
\text { (d 15-28) }\end{array}$ & $\begin{array}{l}\text { Finisher } \\
\text { (d 29-42) }\end{array}$ \\
\hline \multicolumn{4}{|l|}{ Ingredients, $\mathbf{g} / \mathbf{k g}$} \\
\hline Corn & 572.70 & 613.70 & 641.50 \\
\hline SBM-48 & 360.00 & 320.00 & 290.00 \\
\hline Soybean oil & 28.00 & 31.00 & 37.00 \\
\hline Limestone & 14.00 & 14.00 & 13.00 \\
\hline Monocalcium phosphate & 9.00 & 6.50 & 5.00 \\
\hline Lysine & 3.50 & 3.00 & 2.50 \\
\hline Methionine & 2.50 & 1.90 & 1.40 \\
\hline Threonine & 1.00 & 1.00 & 1.00 \\
\hline $\mathrm{NaCl}$ & 3.00 & 2.80 & 2.50 \\
\hline Sodium bicarbonate & 1.20 & 1.00 & 1.00 \\
\hline Vitamin+mineral mix ${ }^{\mathrm{a}}$ & 5.00 & 5.00 & 5.00 \\
\hline Phytase & 0.10 & 0.10 & 0.10 \\
\hline \multicolumn{4}{|l|}{ Calculated content, $\mathrm{g} / \mathrm{kg}$} \\
\hline $\mathrm{ME}, \mathrm{MJ} / \mathrm{kg}$ & 12.83 & 13.11 & 13.43 \\
\hline Crude protein & 222.80 & 204.77 & 190.85 \\
\hline NDF & 79.20 & 79.61 & 79.65 \\
\hline Crude fat & 26.64 & 25.98 & 25.42 \\
\hline dig Lys & 13.50 & 12.13 & 11.00 \\
\hline digMet & 5.61 & 4.84 & 4.22 \\
\hline dig Thr & 7.54 & 7.01 & 6.61 \\
\hline Trp & 3.01 & 2.74 & 2.53 \\
\hline Meth+Cysteine & 10.20 & 9.26 & 8.48 \\
\hline $\operatorname{Arg}$ & 15.28 & 14.08 & 13.17 \\
\hline Val & 10.86 & 10.17 & 9.65 \\
\hline lle & 9.29 & 8.56 & 8.01 \\
\hline Leu & 19.19 & 18.11 & 17.26 \\
\hline $\mathrm{Ca}$ & 9.40 & 8.85 & 8.12 \\
\hline Total P & 7.23 & 6.57 & 6.15 \\
\hline Available P & 4.55 & 3.99 & 3.65 \\
\hline $\mathrm{Na}$ & 2.01 & 1.87 & 1.75 \\
\hline $\mathrm{Cl}$ & 2.22 & 2.09 & 1.91 \\
\hline Choline & 1.34 & 1.25 & 1.19 \\
\hline \multicolumn{4}{|c|}{ Analyzed composition, as is, $\mathrm{g} / \mathrm{kg}$} \\
\hline $\mathrm{DM}$ & 877.6 & 876.2 & 882.0 \\
\hline Gross energy, MJ/kg & 15.86 & 16.11 & 16.4 \\
\hline Crude protein & 227.82 & 210.91 & 192.95 \\
\hline Crude fat & 31.10 & 37.77 & 52.78 \\
\hline Crude fiber & 22.93 & 22.44 & 22.00 \\
\hline ADF & 34.46 & 33.09 & 39.60 \\
\hline NDF & 77.25 & 78.13 & 85.97 \\
\hline Ash & 53.14 & 48.27 & 46.82 \\
\hline
\end{tabular}

a Provides following nutrients (per $\mathrm{kg}$ of diet): vitamin $\mathrm{A}$ (trans-retinyl acetate), $10,000 \mathrm{IU}$; vitamin $\mathrm{D}_{3}$ (cholecalciferol), 3,000 IU; vitamin $\mathrm{E}$ (all-rac-tocopherol-acetate), 30 $\mathrm{mg}$; vitamin $\mathrm{B}_{1}, 2 \mathrm{mg}$; vitamin $\mathrm{B}_{2}, 8 \mathrm{mg}$; vitamin $\mathrm{B}_{6}, 4 \mathrm{mg}$; vitamin $\mathrm{B}_{12}$ (cyanocobalamin), $0.025 \mathrm{mg}$; vitamin $\mathrm{K}_{3}$ (bisulphatemenadione complex), 3mg; choline (choline chloride), $250 \mathrm{mg}$; nicotinic acid, $60 \mathrm{mg}$; pantothenic acid (D-calcium pantothenate), $15 \mathrm{mg}$; folic acid, $1.5 \mathrm{mg}$; betaíne anhydrous, $80 \mathrm{mg}$; D-biotin, $0.15 \mathrm{mg} ;$ zinc (ZnO), $80 \mathrm{mg}$; manganese ( $\mathrm{MnO}), 70 \mathrm{mg}$ iron $\left(\mathrm{FeCO}_{3}\right), 60 \mathrm{mg}$; copper $\left(\mathrm{CuSO}_{4} \cdot 5 \mathrm{H}_{2} \mathrm{O}\right), 8 \mathrm{mg}$; iodine $(\mathrm{KI}), 2 \mathrm{mg}$; selenium $\left(\mathrm{Na}_{2} \mathrm{SeO}\right)_{3}, 0.2 \mathrm{mg}$.

${ }^{\mathrm{b}}$ The basal diets in all phases were top-dressed with the combination of 3 levels of xylanase $(0 \mathrm{BXU} / \mathrm{kg}, 8,000 \mathrm{BXU} / \mathrm{kg}$ and $16,000 \mathrm{BXU} / \mathrm{kg})$ and 3 levels of xylooligosaccharides $(0 \mathrm{~g} / \mathrm{t}, 50 \mathrm{~g} / \mathrm{t}$ and $100 \mathrm{~g} / \mathrm{t})$ to yield 9 treatments 
was recorded, and 2 birds from each pen, making 8 birds for each treatment, were euthanized using $\mathrm{CO}_{2}$. The cecal contents were collected, snap-frozen, and stored at $-20{ }^{\circ} \mathrm{C}$ until further analysis for SCFA. Simultaneously, another set of cecal contents were collected from 1 bird per pen in cryovials and snap-frozen and transferred to a $-80{ }^{\circ} \mathrm{C}$ freezer for later DNA extraction and microbiota analysis. Next, approximately $2-3 \mathrm{~cm}$ section of the ileum (defined as the section between Meckel's diverticulum and ileocecal junction) was cut from 2 birds and fixed in $10 \%$ buffered formalin for histomorphometry. Moreover, the weight of the liver, gizzard, proventriculus, drumsticks, whole breast, and abdominal fat was recorded from 1 bird per pen for each treatment to calculate the relative organ and carcass weight (\% of live body weight).

\section{Proximate analysis and enzyme activity}

The nutrient profile of feed samples was analyzed for dry matter (DM), gross energy (GE), $\mathrm{N}$ (for crude protein, $\mathrm{CP}$ ), crude fat, ash, crude fiber, neutral detergent fiber (NDF), and acid detergent fiber (ADF) using the standard procedures of Association of Official Agricultural Chemists [19] (Table 1). The enzyme activity levels in the final feed samples $(200 \mathrm{~g})$ were measured at the AB Vista Innovation and Technology Center (Tredomen Park, Ystrad Mynach, UK) in duplicate and were reported as activity units. The amount of enzyme that produces $1 \mathrm{nmol}$ of xylan, a reducing sugar from birch xylan in $1 \mathrm{~s}$ at $50{ }^{\circ} \mathrm{C}$ at $\mathrm{pH} 5.3$ is defined as one xylanase units (BXU). The enzyme activity recovery in the final feed of all phases in the no xylanase groups was less than $2,000 \mathrm{BXU} / \mathrm{kg}$. Xylanase activity was about $100 \%-115 \%$ of expected levels in the starter, about $95 \%-110 \%$ in grower, and about $95 \%-105 \%$ in the finisher diets, thus confirmed the activity to be within $15 \%$ of the targeted levels.

\section{Chromatographic analysis of short-chain fatty acids}

The cecal digesta was analyzed for major SCFA by gas chromatography using GC system (Trace 1300, Thermo Scientific, Waltham, MA, USA) equipped with a flame ionization detector and AS 1310 series automatic liquid sampler, according to Singh et al. [4]. A calibration curve of the external standard was made in the range of 0 $8 \mathrm{mmol} / \mathrm{L}$ using SCFA mix (Sigma-Aldrich, St. Louis, MO, USA). Trimethylacetic acid (Sigma-Aldrich, St. Louis, MO, USA) was used as an internal standard. The standard SCFA mix was analyzed by GC to get an individual calibration curve for each external standard compound based on their response ratio to the internal standard. SCFA data handling and processing were performed on ChromeleonTM 7.2 software (Thermo Scientific, Waltham, MA, USA).

\section{Histomorphometry of ileal mucosa}

The formalin-fixed ileal samples $(n=4$ per treatment) were transferred to $70 \%$ ethanol the next day, and embedding, sectioning $(5 \mu \mathrm{m})$ and Hematoxylin and Eosin (H\&E) staining was done at John A. Burns School of Medicine histology core of University of Hawaii at Manoa. Each slide had 6 ileal cross-sections, and 3 welloriented sets of villus and crypts for each section was observed at $8 \times$ magnification of objective under a microscope (Olympus BX43, Olympus Co, Tokyo, Japan) fitted with camera and image processing Infinity Analyze software (Lumenera Corporation, Ottawa, ON, Canada). The villus height $(\mathrm{VH})$ was measured from the tip of mucosal projection to the invagination creating a valley between two mucosal projections. The crypt depth (CD) was measured from the opening of the invagination to the base above the lamina muscularis mucosae. The $\mathrm{VH}$ : $\mathrm{CD}$ ratio was calculated, and the average of each pen was recorded.

\section{RNA extraction and gene expression analysis}

Frozen ileal tissue (50-100 mg) was homogenized in $300 \mu \mathrm{l}$ of TRIzol ${ }^{\circ}$ (Invitrogen, Carlsbad, CA) with 9-11 Zirconia beads (BioSpec Products, Bartlesville, OK, USA) of $2.3 \mathrm{~mm}$ diameter. The homogenization was carried out by bead beating in a nuclease-free safe lock Eppendorf tube on a vertical Bullet Blender ${ }^{\circ}$ (Next Advance, Inc. Troy, NY) for 2-3 min at speed 8. Next, the homogenized sample was centrifuged at $10,000 \mathrm{r} / \mathrm{min}$ at $4{ }^{\circ} \mathrm{C}$ for $1 \mathrm{~min}$, and $250 \mu \mathrm{L}$ of the supernatant was pipetted and mixed with $750 \mu \mathrm{L}$ of TRIzol ${ }^{\circ}$ in a new microcentrifuge tube. Total RNA extraction, quality assessment, and cDNA preparation were done according to the procedure described by Wasti et al. [20]. The primers used in this study were designed on the NCBI primer blast tool for immune gene markers that were used previously [21]. The program for amplification was set as $50{ }^{\circ} \mathrm{C}$ for $2 \mathrm{~min}$ then $95^{\circ} \mathrm{C}$ for $2 \mathrm{~min}$ that was followed by 40 cycles at $95{ }^{\circ} \mathrm{C}$ for $15 \mathrm{~s}$ for denaturation, annealing at $60{ }^{\circ} \mathrm{C}$ for $15 \mathrm{~s}$, and extension at $72{ }^{\circ} \mathrm{C}$ for $1 \mathrm{~min}$. After 40 cycles of qPCR, melt curves were generated to ensure the specificity of the primers used. The target genes were analyzed in duplicate, and the Beta-actin ( $\beta$-actin) housekeeping gene was analyzed in triplicate, and an average value was recorded for all experimental replicates. After the qPCR run was complete, the cycle of threshold $(\mathrm{Ct})$ was noted for each gene marker. The gene expression was calculated as relative quantification for each target gene using the base 2 exponential negative delta- delta $\mathrm{Ct}$ $\left(2^{-\Delta \Delta \mathrm{Ct}}\right)$ method. The mean $\Delta \mathrm{Ct}$ of $0 \%$ xylanase $+0 \%$ $\mathrm{XOS}$ was used to calculate the $\Delta \Delta \mathrm{Ct}$ of each treatment.

\section{Bioinformatic analysis of $16 \mathrm{~S}$ rRNA amplicon}

Cecal microbial DNA was extracted using QIAamp ${ }^{\circ}$ Fast DNA Stool Mini Kit (Qiagen, Hilden, Germany) according 
to the manufacturer's instructions. The library preparation was performed by amplicon PCR with primers targeting V3-V4 variable regions of the 16S rRNA gene. The forward primer sequence was 5'-TCGTCGGCAGCGTCA GATGTGTATAAGAGACAGCCTACGGGNGGCWG CAG-3' and reverse primer sequence was $5^{\prime}$-TCTC GTGGGCTCGGAGATGTGTATAAGAGACAGGAC TACHVGGGTATCTAATCC-3', containing Illumina overhang adapter and locus-specific sequence for $16 \mathrm{~S}$ rRNA amplification [22]. The amplicon PCR, product cleaning, and attaching of Nextera XT dual indices to the amplicon was performed as previously described by Singh et al. [4].

For further processing, Quantitative Insights Into Microbial Ecology (QIIME ${ }^{\text {tix }}$ version 2.0 release 2019.4) was used to import demultiplexed paired-end reads of $300 \mathrm{bp}$ in length for all samples [23]. After importing into QIIME2, the DADA2 pipeline was used to denoise, trim, and filter these paired-end sequences. The filtered sequences were subjected to align-to-tree-mafft-fasttree

Table 2 Effects of supplemental xylanase and xylooligosaccharides on growth performance of broilers in different dietary phases from d 0-42 post-hatch

\begin{tabular}{|c|c|c|c|c|c|c|c|c|c|c|c|c|c|}
\hline \multirow[t]{3}{*}{ Treatments } & \multicolumn{13}{|c|}{ Variables } \\
\hline & \multicolumn{4}{|c|}{ ADFI, g/day } & \multicolumn{4}{|c|}{ ADG, g/day } & \multicolumn{4}{|l|}{ FCR } & \multirow{2}{*}{$\frac{\text { FBWG, }}{0-42}$} \\
\hline & $0-14$ & $15-28$ & $29-42$ & $0-42$ & $0-14$ & $15-28$ & $29-42$ & $0-42$ & $0-14$ & $15-28$ & $29-42$ & $0-42$ & \\
\hline \multicolumn{14}{|l|}{ O BXU xylanase } \\
\hline Xylo-oligo, $0 \mathrm{~g} / \mathrm{t}$ & 36.0 & 109.0 & 171.2 & 105.4 & 27.0 & 75.6 & 91.9 & 64.9 & 1.34 & 1.44 & 1.87 & 1.63 & 2,694 \\
\hline Xylo-oligo, $50 \mathrm{~g} / \mathrm{t}$ & 36.3 & 109.0 & 175.7 & 107.0 & 27.9 & 76.7 & 94.7 & 66.4 & 1.31 & 1.42 & 1.86 & 1.61 & 2,800 \\
\hline Xylo-oligo, 100 g/t & 36.4 & 109.9 & 173.7 & 106.7 & 28.2 & 77.5 & 92.9 & 66.2 & 1.29 & 1.42 & 1.88 & 1.61 & 2,786 \\
\hline \multicolumn{14}{|l|}{ 8,000 BXU xylanase } \\
\hline Xylo-oligo, 0 g/t & 36.3 & 110.5 & 177.5 & 108.1 & 27.7 & 77.5 & 97.9 & 67.7 & 1.31 & 1.43 & 1.81 & 1.60 & 2,890 \\
\hline Xylo-oligo, $50 \mathrm{~g} / \mathrm{t}$ & 36.6 & 110.9 & 179.3 & 108.9 & 28.3 & 79.7 & 96.9 & 68.3 & 1.30 & 1.39 & 1.86 & 1.60 & 2,959 \\
\hline Xylo-oligo, $100 \mathrm{~g} / \mathrm{t}$ & 36.7 & 111.6 & 179.2 & 109.2 & 28.7 & 80.2 & 98.6 & 69.2 & 1.28 & 1.39 & 1.82 & 1.58 & 2,972 \\
\hline \multicolumn{14}{|l|}{16,000 BXU xylanase } \\
\hline Xylo-oligo, 0 g/t & 36.7 & 111.4 & 179.4 & 109.2 & 28.5 & 78.3 & 98.8 & 68.5 & 1.29 & 1.43 & 1.82 & 1.60 & 2,909 \\
\hline Xylo-oligo, $50 \mathrm{~g} / \mathrm{t}$ & 36.7 & 112.2 & 178.4 & 109.1 & 28.8 & 79.9 & 98.9 & 69.2 & 1.28 & 1.41 & 1.82 & 1.58 & 2,946 \\
\hline Xylo-oligo, $100 \mathrm{~g} / \mathrm{t}$ & 36.8 & 111.2 & 179.2 & 109.0 & 29.1 & 80.5 & 98.5 & 69.4 & 1.26 & 1.38 & 1.82 & 1.57 & 2,941 \\
\hline $\operatorname{SEM}(n=4)$ & 0.50 & 1.70 & 3.47 & 1.56 & 0.87 & 1.76 & 2.44 & 1.33 & 0.04 & 0.02 & 0.04 & 0.02 & 65.02 \\
\hline \multicolumn{14}{|l|}{ Main effect factors } \\
\hline \multicolumn{14}{|l|}{ Xylanase } \\
\hline O BXU xylanase & 36.2 & 109.3 & 173.5 & 106.4 & 27.7 & 76.6 & $93.2^{b}$ & $65.8^{b}$ & 1.31 & 1.43 & 1.87 & 1.62 & $2,760^{b}$ \\
\hline 8000 BXU xylanase & 36.5 & 111.0 & 178.7 & 108.7 & 28.3 & 79.1 & $97.8^{\mathrm{ab}}$ & $68.4^{\mathrm{ab}}$ & 1.30 & 1.40 & 1.83 & 1.59 & $2,940^{a}$ \\
\hline 16,000 BXU xylanase & 36.7 & 111.6 & 179.0 & 109.1 & 28.8 & 79.6 & $98.7^{\mathrm{a}}$ & $69.0^{a}$ & 1.28 & 1.40 & 1.82 & 1.58 & $2,932^{a}$ \\
\hline \multicolumn{14}{|l|}{ Xylooligosaccharides } \\
\hline Xylo-oligo, 0 g/t & 36.3 & 110.3 & 176.0 & 107.6 & 27.7 & 77.1 & 96.2 & 67.0 & 1.31 & 1.43 & 1.84 & 1.61 & 2,831 \\
\hline Xylo-oligo, $50 \mathrm{~g} / \mathrm{t}$ & 36.5 & 110.7 & 177.8 & 108.3 & 28.3 & 78.8 & 96.8 & 68.0 & 1.29 & 1.41 & 1.84 & 1.59 & 2,902 \\
\hline Xylo-oligo, $100 \mathrm{~g} / \mathrm{t}$ & 36.6 & 110.9 & 177.4 & 108.3 & 28.7 & 79.4 & 96.7 & 68.3 & 1.28 & 1.40 & 1.84 & 1.59 & 2,900 \\
\hline $\operatorname{SEM}(n=12)$ & 0.29 & 0.98 & 2.01 & 0.90 & 0.50 & 1.02 & 1.41 & 0.77 & 0.02 & 0.01 & 0.02 & 0.01 & 37.54 \\
\hline \multicolumn{14}{|l|}{$P$-value } \\
\hline Xylanase & 0.490 & 0.247 & 0.114 & 0.081 & 0.317 & 0.108 & 0.020 & 0.015 & 0.480 & 0.395 & 0.305 & 0.197 & 0.003 \\
\hline \multirow[t]{2}{*}{ Linear } & - & & - & & - & & 0.009 & 0.006 & - & & - & & 0.003 \\
\hline & & - & & - & & - & & & & - & & - & \\
\hline \multirow[t]{2}{*}{ Quadratic } & - & & - & & - & & 0.290 & 0.317 & - & & - & & 0.050 \\
\hline & & - & & - & & - & & & & - & & - & \\
\hline Xylo-oligo & 0.748 & 0.922 & 0.809 & 0.790 & 0.417 & 0.280 & 0.948 & 0.500 & 0.524 & 0.244 & 0.973 & 0.606 & 0.335 \\
\hline Xylanase $\times$ Xylo-oligo & 0.993 & 0.978 & 0.959 & 0.985 & 0.998 & 0.999 & 0.935 & 0.992 & 0.990 & 0.980 & 0.954 & 0.995 & 0.983 \\
\hline
\end{tabular}

$0 \mathrm{BXU}$ xylanase $=0 \mathrm{~g}$ xylanase/ $\mathrm{t}$ feed, 8,000 BXU xylanase $=50 \mathrm{~g}$ xylanase/ $\mathrm{t}$ feed, 16,000 BXU xylanase $=100 \mathrm{~g}$ xylanase/ $\mathrm{t}$ feed. Xylo-oligo: $x y l o o l i g o s a c c h a r i d e s$. $A D F I$ : average daily feed intake, $A D G$ : average daily gain, $F C R$ : feed conversion ratio, FBWG: final body weight gain

${ }^{a-b}$ Within columns in the xylanase main effect, means without a common superscript differ $(P<0.05)$ 
pipeline from the QIIME phylogeny plugin to generate an unrooted and rooted tree for phylogeny. A Naïve Bayes classifier pre-trained on the Greengenes 13_8 99\% OTU was used for taxonomy analysis. The diversity plugin method named core-metrics-phylogenetic was used to conduct alpha and beta diversity analysis on sampling depth of 10,000 frequency. Alpha diversity results were presented as Shannon Index and observed OTUs, while Bray Curtis metrics and unweighted UniFrac were applied for beta diversity. Moreover, we accessed the Clusters of Orthologous Groups of proteins (COGs) and the Kyoto Encyclopedia of Genes and Genomes (KEGG; Uji, Kyoto, Japan) databases to conduct a Phylogenetic Investigation of Communities by Reconstruction of Unobserved States (PICRUSt) to determine the effect of xylanase and XOS on the predictive functional profile of cecal microbiota. For this, a closed-reference OTU table was generated based on the greengenes database. Once the biome file was obtained, a software package Statistical Analysis of Taxonomic and Functional Profiles version 2.1.3 was employed for the processing and presentation of the mean differences [24].

\section{Statistical analysis}

All the data for growth performance variables, relative carcass and organ weight, ileal histomorphometry, and SCFA were subjected to the MIXED procedure of SAS V9.2 (SAS Institute Inc., Cary, NC, USA) to compare the effects of treatments. A probability of $P<0.05$ was considered significant for differences among treatments

Table 3 Effects of xylanase and xylooligosaccharides inclusion on relative organ weight ( $\mathrm{g} / 100 \mathrm{~g}$ live weight) of broilers from d 0-42 post-hatch

\begin{tabular}{|c|c|c|c|c|c|c|}
\hline & \multicolumn{6}{|c|}{ Variables } \\
\hline & Liver & Proventriculus & Gizzard & Breast & Drumstick & Abdominal fat \\
\hline \multicolumn{7}{|l|}{ Treatments } \\
\hline \multicolumn{7}{|l|}{ O BXU Xylanase } \\
\hline Xylo-oligo, 0 g/t & 2.10 & 0.30 & 1.35 & 30.01 & 4.83 & 0.79 \\
\hline Xylo-oligo, $50 \mathrm{~g} / \mathrm{t}$ & 2.02 & 0.32 & 1.34 & 29.06 & 4.36 & 1.34 \\
\hline Xylo-oligo, $100 \mathrm{~g} / \mathrm{t}$ & 2.21 & 0.28 & 1.24 & 29.68 & 4.78 & 1.48 \\
\hline \multicolumn{7}{|l|}{8000 BXU Xylanase } \\
\hline Xylo-oligo, 0 g/t & 2.20 & 0.31 & 1.18 & 30.03 & 4.58 & 1.27 \\
\hline Xylo-oligo, $50 \mathrm{~g} / \mathrm{t}$ & 2.23 & 0.29 & 1.20 & 29.85 & 4.46 & 1.09 \\
\hline Xylo-oligo, $100 \mathrm{~g} / \mathrm{t}$ & 2.07 & 0.27 & 1.11 & 29.98 & 4.22 & 1.08 \\
\hline \multicolumn{7}{|l|}{16,000 BXU Xylanase } \\
\hline Xylo-oligo, 0 g/t & 2.53 & 0.26 & 1.09 & 29.01 & 4.50 & 1.31 \\
\hline Xylo-oligo, $50 \mathrm{~g} / \mathrm{t}$ & 2.22 & 0.27 & 1.08 & 30.90 & 4.70 & 1.21 \\
\hline Xylo-oligo, $100 \mathrm{~g} / \mathrm{t}$ & 2.11 & 0.30 & 1.40 & 27.81 & 4.70 & 1.55 \\
\hline $\operatorname{SEM}(n=4)$ & 0.213 & 0.019 & 0.094 & 1.079 & 0.162 & 0.188 \\
\hline \multicolumn{7}{|l|}{ Main effect factors } \\
\hline \multicolumn{7}{|l|}{ Xylanase } \\
\hline O BXU Xylanase & 2.11 & 0.30 & 1.31 & 29.58 & 4.66 & 1.20 \\
\hline 8000 BXU Xylanase & 2.17 & 0.29 & 1.16 & 29.95 & 4.42 & 1.15 \\
\hline 16,000 BXU Xylanase & 2.29 & 0.28 & 1.19 & 29.24 & 4.63 & 1.36 \\
\hline \multicolumn{7}{|l|}{ Xylo-oligo } \\
\hline Xylo-oligo, 0 g/t & 2.28 & 0.29 & 1.20 & 29.68 & 4.64 & 1.12 \\
\hline Xylo-oligo, $50 \mathrm{~g} / \mathrm{t}$ & 2.16 & 0.29 & 1.21 & 29.94 & 4.51 & 1.21 \\
\hline Xylo-oligo, $100 \mathrm{~g} / \mathrm{t}$ & 2.13 & 0.28 & 1.25 & 29.16 & 4.57 & 1.37 \\
\hline $\operatorname{SEM}(n=12)$ & 0.123 & 0.011 & 0.054 & 0.623 & 0.094 & 0.108 \\
\hline \multicolumn{7}{|l|}{$P$-value } \\
\hline Xylanase & 0.595 & 0.298 & 0.155 & 0.723 & 0.162 & 0.378 \\
\hline Xylo-oligo & 0.673 & 0.899 & 0.808 & 0.669 & 0.622 & 0.279 \\
\hline Xylanase $\times$ Xylo-oligo & 0.740 & 0.302 & 0.102 & 0.452 & 0.135 & 0.156 \\
\hline
\end{tabular}


means that was further separated by the Tukey test using pdmix macro of SAS. The log-transformation was performed for all the fold change data of immune gene expression, and TTest procedure of SAS was applied to compare test variables with control variables. For analysis of microbiota diversity, Kruskal-Wallis pairwise test for alpha diversity and pairwise PERMANOVA for beta diversity were implemented in QIIME 2. White's nonparametric t-test was run for statistical analysis of the predicted functional pathways [25]. The correlogram showing association among various biological parameters was generated using corrplot package, while the heatmap was constructed using pheatmap package of $\mathrm{R}$ software based on Spearman's rank correlation. The level

Table 4 Effects of supplemental xylanase and xylooligosaccharides on ileum histomorphology of broiler chickens on d 42 post-hatch

\begin{tabular}{|c|c|c|c|}
\hline \multirow[t]{2}{*}{ Treatments } & \multicolumn{3}{|c|}{ Variables, $\mu \mathrm{m}$} \\
\hline & $\overline{\mathrm{VH}}$ & $\mathrm{CD}$ & VH: CD \\
\hline \multicolumn{4}{|l|}{ O BXU xylanase } \\
\hline Xylo-oligo, 0 g/t & 865.2 & 98.7 & 8.9 \\
\hline Xylo-oligo, $50 \mathrm{~g} / \mathrm{t}$ & 817.5 & 87.8 & 9.4 \\
\hline Xylo-oligo, 100 g/t & 879.7 & 92.7 & 9.6 \\
\hline \multicolumn{4}{|l|}{8000 BXU xylanase } \\
\hline Xylo-oligo, 0 g/t & 883.9 & 96.4 & 9.3 \\
\hline Xylo-oligo, $50 \mathrm{~g} / \mathrm{t}$ & 995.4 & 102.4 & 9.8 \\
\hline Xylo-oligo, $100 \mathrm{~g} / \mathrm{t}$ & 886.0 & 91.6 & 9.8 \\
\hline \multicolumn{4}{|l|}{16,000 BXU xylanase } \\
\hline Xylo-oligo, 0 g/t & 963.4 & 98.2 & 9.9 \\
\hline Xylo-oligo, $50 \mathrm{~g} / \mathrm{t}$ & $1,101.6$ & 111.3 & 10.0 \\
\hline Xylo-oligo, $100 \mathrm{~g} / \mathrm{t}$ & 928.8 & 93.0 & 10.1 \\
\hline $\operatorname{SEM}(n=4)$ & 82.30 & 7.31 & 0.38 \\
\hline \multicolumn{4}{|l|}{ Main effect factors } \\
\hline \multicolumn{4}{|l|}{ Xylanase } \\
\hline 0 BXU xylanase & 854.1 & 93.0 & 9.3 \\
\hline 8000 BXU xylanase & 921.8 & 96.8 & 9.6 \\
\hline 16,000 BXU xylanase & 997.9 & 100.8 & 10.0 \\
\hline \multicolumn{4}{|l|}{ Xylooligosaccharides } \\
\hline Xylo-oligo, 0 g/t & 904.2 & 97.7 & 9.3 \\
\hline Xylo-oligo, $50 \mathrm{~g} / \mathrm{t}$ & 971.5 & 100.5 & 9.7 \\
\hline Xylo-oligo, 100 g/t & 898.2 & 92.4 & 9.8 \\
\hline $\operatorname{SEM}(n=12)$ & 47.51 & 4.22 & 0.22 \\
\hline \multicolumn{4}{|l|}{$P$-value } \\
\hline Xylanase & 0.120 & 0.438 & 0.097 \\
\hline Xylo-oligo & 0.489 & 0.399 & 0.248 \\
\hline Xylanase $\times$ Xylo-oligo & 0.646 & 0.468 & 0.965 \\
\hline
\end{tabular}

of significance for biological parameters and microbiota association was set at $P<0.05$.

\section{Results}

The calculated nutrients in the feed formulation in different phases diet were similar to the proximate estimates (Table 1). Xylanase and XOS had no interaction effects on growth parameters and did not vary ADFI and FCR from d $0-42$ in any rearing phases $(P>0.05$; Table 2$)$. However, during the total period, a trend $(P=0.081)$ was observed for the effect of xylanase on ADFI, where the increasing level of xylanase increased the ADFI. In the finisher and total period, ADG was linearly $(P<0.01)$ increased by

Table 5 Effects of supplemental xylanase and xylooligosaccharides on the production of cecal short-chain fatty acids ( $\mathrm{mmol} / \mathrm{kg}$ wet digesta) in broilers on d 42 post-hatch

\begin{tabular}{|c|c|c|c|c|}
\hline \multirow[t]{2}{*}{ Treatments } & \multicolumn{4}{|c|}{ Variables, $\mathrm{mmol} / \mathrm{kg}$} \\
\hline & Acetate & Propionate & Butyrate & Total SCFA \\
\hline \multicolumn{5}{|l|}{0 BXU xylanase } \\
\hline Xylo-oligo, 0 g/t & 50.2 & 5.4 & 6.3 & 64.9 \\
\hline Xylo-oligo, $50 \mathrm{~g} / \mathrm{t}$ & 58.5 & 4.7 & 10.0 & 76.2 \\
\hline Xylo-oligo, $100 \mathrm{~g} / \mathrm{t}$ & 57.2 & 5.5 & 10.8 & 76.8 \\
\hline \multicolumn{5}{|l|}{8000 BXU xylanase } \\
\hline Xylo-oligo, 0 g/t & 68.0 & 6.5 & 9.7 & 87.5 \\
\hline Xylo-oligo, $50 \mathrm{~g} / \mathrm{t}$ & 66.6 & 5.9 & 8.0 & 84.1 \\
\hline Xylo-oligo, 100 g/t & 71.0 & 6.0 & 10.1 & 90.7 \\
\hline \multicolumn{5}{|l|}{16,000 BXU xylanase } \\
\hline Xylo-oligo, 0 g/t & 70.9 & 5.8 & 9.7 & 89.8 \\
\hline Xylo-oligo, 50 g/t & 77.0 & 6.3 & 11.0 & 97.8 \\
\hline Xylo-oligo, 100 g/t & 80.4 & 5.3 & 9.3 & 98.4 \\
\hline $\operatorname{SEM}(n=4)$ & 2.74 & 0.92 & 1.18 & 3.82 \\
\hline \multicolumn{5}{|l|}{ Main effect factors } \\
\hline \multicolumn{5}{|l|}{ Xylanase } \\
\hline 0 BXU xylanase & $55.3^{c}$ & 5.2 & 9.0 & $72.6^{c}$ \\
\hline 8000 BXU xylanase & $68.5^{\mathrm{b}}$ & 6.1 & 9.3 & $87.4^{b}$ \\
\hline 16,000 BXU xylanase & $76.1^{\mathrm{a}}$ & 5.8 & 10.0 & $95.3^{\mathrm{a}}$ \\
\hline \multicolumn{5}{|l|}{ Xylooligosaccharides } \\
\hline Xylo-oligo, 0 g/t & $63.0^{\mathrm{b}}$ & 5.9 & 8.5 & $80.7^{b}$ \\
\hline Xylo-oligo, $50 \mathrm{~g} / \mathrm{t}$ & $67.4^{\mathrm{ab}}$ & 5.6 & 9.7 & $86.0^{\mathrm{ab}}$ \\
\hline Xylo-oligo, $100 \mathrm{~g} / \mathrm{t}$ & $69.6^{\mathrm{a}}$ & 5.6 & 10.1 & $88.6^{a}$ \\
\hline $\operatorname{SEM}(n=12)$ & 1.58 & 0.53 & 0.68 & 2.21 \\
\hline \multicolumn{5}{|l|}{$P$-value } \\
\hline Xylanase & $<0.001$ & 0.479 & 0.558 & $<0.001$ \\
\hline Xylo-oligo & 0.022 & 0.923 & 0.264 & 0.052 \\
\hline Xylanase $\times$ Xylo-oligo & 0.409 & 0.907 & 0.102 & 0.404 \\
\hline
\end{tabular}

0 BXU xylanase $=0 \mathrm{~g}$ xylanase $/$ ton feed, 8,000 BXU xylanase $=50 \mathrm{~g}$ xylanase/ ton feed, $16,000 \mathrm{BXU}$ xylanase $=100 \mathrm{~g}$ xylanase/ ton feed Xylo-oligo: xylooligosaccharides, SCFA: short chain fatty acid a-c Within columns in the xylanase and xylooligosaccharides main effects, means without a common superscript differ $(P<0.05)$ 
xylanase. Xylanase also linearly $(P<0.01)$ increased the final body weight gain (FBWG) of broilers by more than $170 \mathrm{~g}$ (2940 \& 2932 vs. $2760 \mathrm{~g}$ ) compared with the control at d $42(P<0.05)$. In contrast, the numerically higher ADG and FBWG in the XOS groups were not statistically different from the control $(P>0.05)$. The effects of xylanase, XOS, and their interaction were not significantly different $(P>0.05)$ for the relative weight of the liver, gizzard, proventriculus, drumsticks, breast, and abdominal fat (Table 3). Ileal mucosa VH and CD were not affected by treatments $(P>0.05$; Table 4$)$. Xylanase exhibited a trend on the $\mathrm{VH}$ to $\mathrm{CD}$ ratio $(P=0.097)$. On $\mathrm{d} 42$, xylanase and XOS increased $(P<0.05)$ the concentration of acetate in the ceca in a dose-dependent manner, but no interaction was observed for any SCFA (Table 5). Xylanase and XOS did not affect the cecal concentration of butyrate and propionate $(P>0.05)$. While XOS had a trend $(P=$ $0.052)$, xylanase significantly $(P<0.01)$ increased the cecal concentration of the total SCFA $(P<0.01)$.

The immune markers of T-cell (CD3) and B-cell (chB6) in the ileum were not different $(P>0.05)$ across treatments on d 42 (Fig. 1). Compared with control, $100 \mathrm{~g} / \mathrm{t}$ XOS with no xylanase supplementation expressed a higher level of IL-4 (a T-cell differentiation cytokine) and IL-10 (a marker of antiinflammatory cytokine) in the ileum $(P<0.05)$. The XOS and xylanase supplementation did not differentially affect the abundance $(P>0.05)$ of any specific phyla of bacteria (Fig. 2). Despite the variability among replicates, Firmicutes was the most abundant phylum, while Bacteroidetes was the second most abundant phylum across all treatments. No significant differences
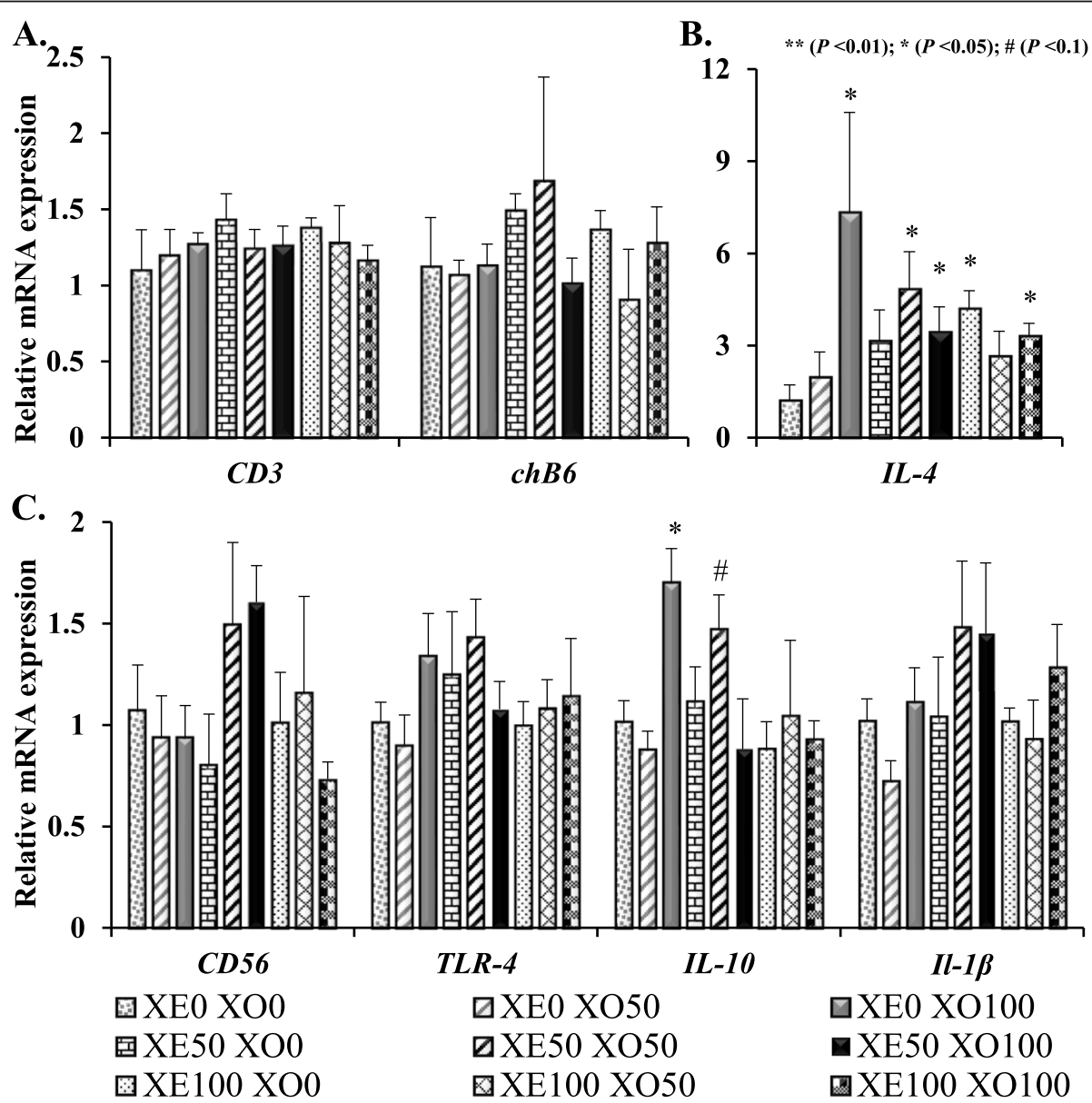

Fig. 1 Effects of xylanase (XE) and xylooligosaccharides $(X O)$ inclusion in feed on ileal gene markers of immune cells of broilers at $d 42$ posthatch. The expression of each gene was examined using RT-qPCR and expressed as fold change ratio to the $\beta$-actin housekeeping gene, with the level being set to 1 in broilers from xylanase $0+$ xylooligosaccharides 0 group. XEO $=x y l a n a s e ~ 0 ~ B X U / k g$ or $0 \mathrm{~g}$ per ton feed, XE50=xylanase 8,000 $\mathrm{BXU} / \mathrm{kg}$ or $50 \mathrm{~g}$ per ton feed, $\mathrm{XE100}=x y l a n a s e 16,000 \mathrm{BXU} / \mathrm{kg}$ or $100 \mathrm{~g}$ per ton feed. $\mathrm{XO}=0 \mathrm{~g}$ xylooligosaccharides per ton feed, $\mathrm{XO} 50=50 \mathrm{~g}$ xylooligosaccharides per ton feed, $\mathrm{XO100}=100 \mathrm{~g}$ xylooligosaccharides per ton feed. CD3 (cluster of differentiation 3) is a marker gene for T-cell. chB6 is a B-cell marker gene. IL-4 is a T-cell differentiation cytokine. CD56 (known as neural cell adhesion molecule) is a gene marker for natural killer cells. TLR-4 (Toll-like receptor 4) is a gene marker for macrophages. IL-10 (interleukin 10) is an anti-inflammatory cytokine. IL-1 $\beta$ is a pro-inflammatory cytokine 

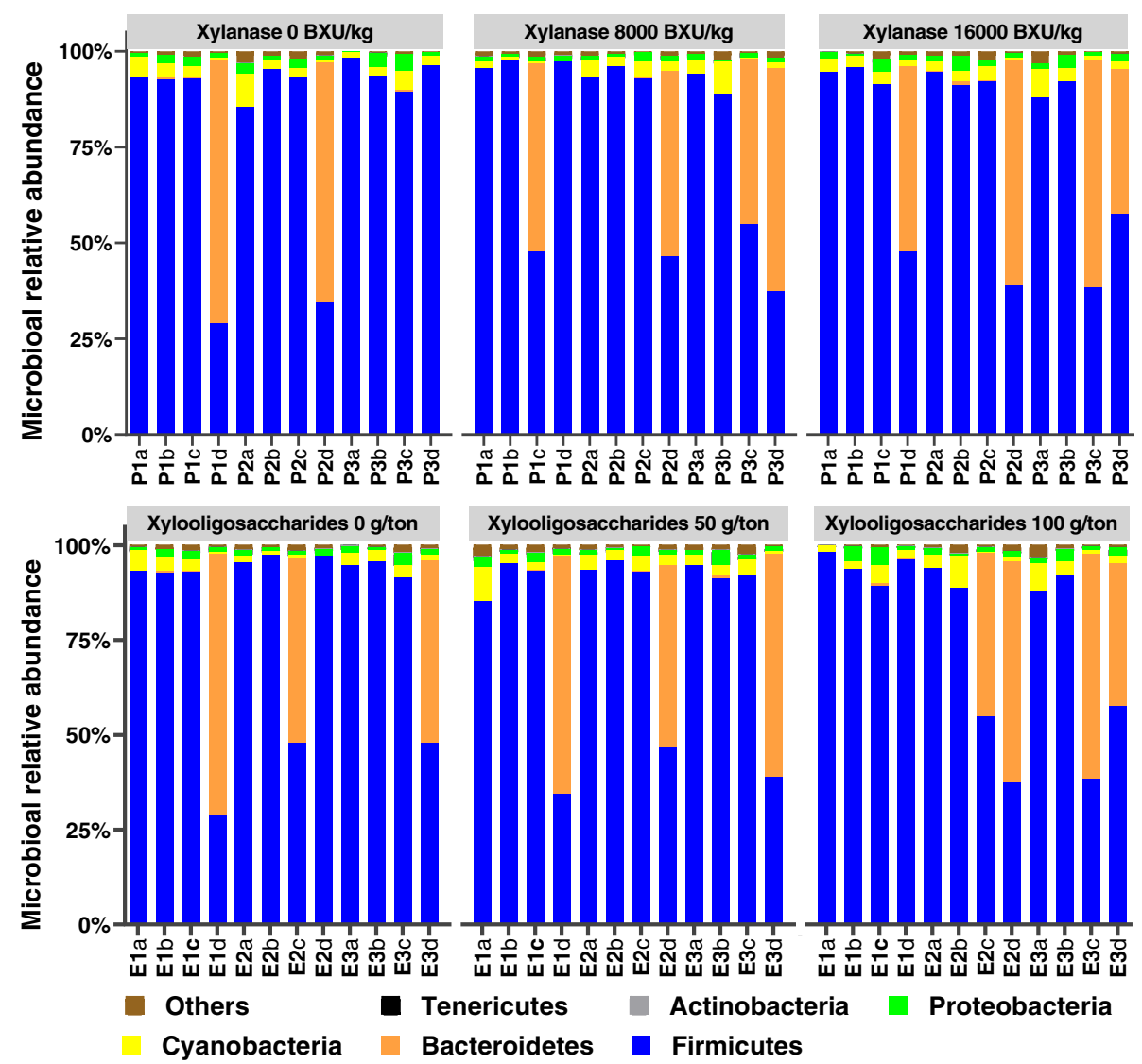

Fig. 2 Stacked bar graph displays a comparison of microbial relative abundance (\%) at phylum level among main effects (xylanase and xylooligosaccharides) of treatments in broilers at $\mathrm{d} 42$ post-hatch. The label $\mathrm{P}$ denotes xylooligosaccharides prebiotics, and the label $\mathrm{E}$ denotes xylanase enzyme for each sample. The letters ( $\mathrm{a}, \mathrm{b}$, c, and d) denote replicate samples. P1: $0 \mathrm{~g}$ xylooligosaccharides per ton feed, P2: $50 \mathrm{~g}$ xylooligosaccharides per ton feed, P3: $100 \mathrm{~g}$ xylooligosaccharides per ton feed. E1: xylanase 0 BXU/kg or $0 \mathrm{~g}$ per ton feed, E2: xylanase 8,000 BXU/kg or $50 \mathrm{~g}$ per ton feed, E3: xylanase16,000 BXU/kg or 100 g per ton feed

$(P>0.05)$ were observed in pairwise comparison across all treatment combinations when compared for the alpha diversity based on the richness of OTUs, and the richness and evenness of bacterial communities based on the Shannon index (Fig. 3). Likewise, the UniFrac and Bray Curtis measure of beta diversity for the differential communities were not significantly different $(P>0.05)$ between treatments (Fig. 4). However, further microbiota analysis between xylanase $0 \mathrm{BXU} / \mathrm{kg}$ and xylanase $16,000 \mathrm{BXU} / \mathrm{kg}$ groups revealed a higher $(P<0.05)$ mean proportion of Papillibacter cinnamivorans and a trend $(P=0.055)$ for a lower mean proportion of an unclassified bacterial species in the order of Clostridiales in the high xylanase group compared with no xylanase group (Fig. 5a).

The predicted functions of cecal microbial communities showed that there was a significant difference $(P<$ 0.05 ) between xylanase $0 \mathrm{BXU} / \mathrm{kg}$ and xylanase 16,000 $\mathrm{BXU} / \mathrm{kg}$ for linoleic acid metabolism (Fig. 5b). Trends $(P<0.1)$ between xylanase $0 \mathrm{BXU} / \mathrm{kg}$ and xylanase 16 , $000 \mathrm{BXU} / \mathrm{kg}$ (for Staphylococcus aureus infection and pyrimidine metabolism) as well as XOS $0 \mathrm{~g} / \mathrm{t}$ and XOS
$100 \mathrm{~g} / \mathrm{t}$ (for transcription machinery and photosynthesis proteins) for predicted functions of cecal microbiota was observed (Fig. 5b, c). However, the difference in the mean proportion between these groups for these predicted functions was not large.

The associations between the growth parameters, carcass yield, and metabolites of all treatments displayed a negative correlation of relative weight of drumstick with butyrate, ADG, and live weight $(\rho=-0.34$ to $-0.39 ; P<0.05$; Fig. 6 , Table S2). The relative weight of the gizzard was negatively correlated with acetate, propionate, butyrate, and total SCFA, as well as live weight ( $\rho=-0.33$ to $-0.41 ; P<0.05$ ). Abdominal fat was negatively correlated with propionate $(\rho=-0.33$; $P<0.05)$. The relative weight of the breast was positively correlated with propionate and live weight $(\rho=0.41$ to $0.43 ; P<$ 0.05 ). In correlation analysis of all treatments for the association between cecal microbiota and biological parameters of broilers, FCR was positively correlated with Bacteroides acidifaciens ( $\rho=0.34 ; P<0.05$; Fig. 7 , Table S2). Live weight was correlated positively $(\rho=0.34)$ with Clostridium ruminantium, and negatively ( $\rho=-0.33$ to -0.34 ) with Clostridium 

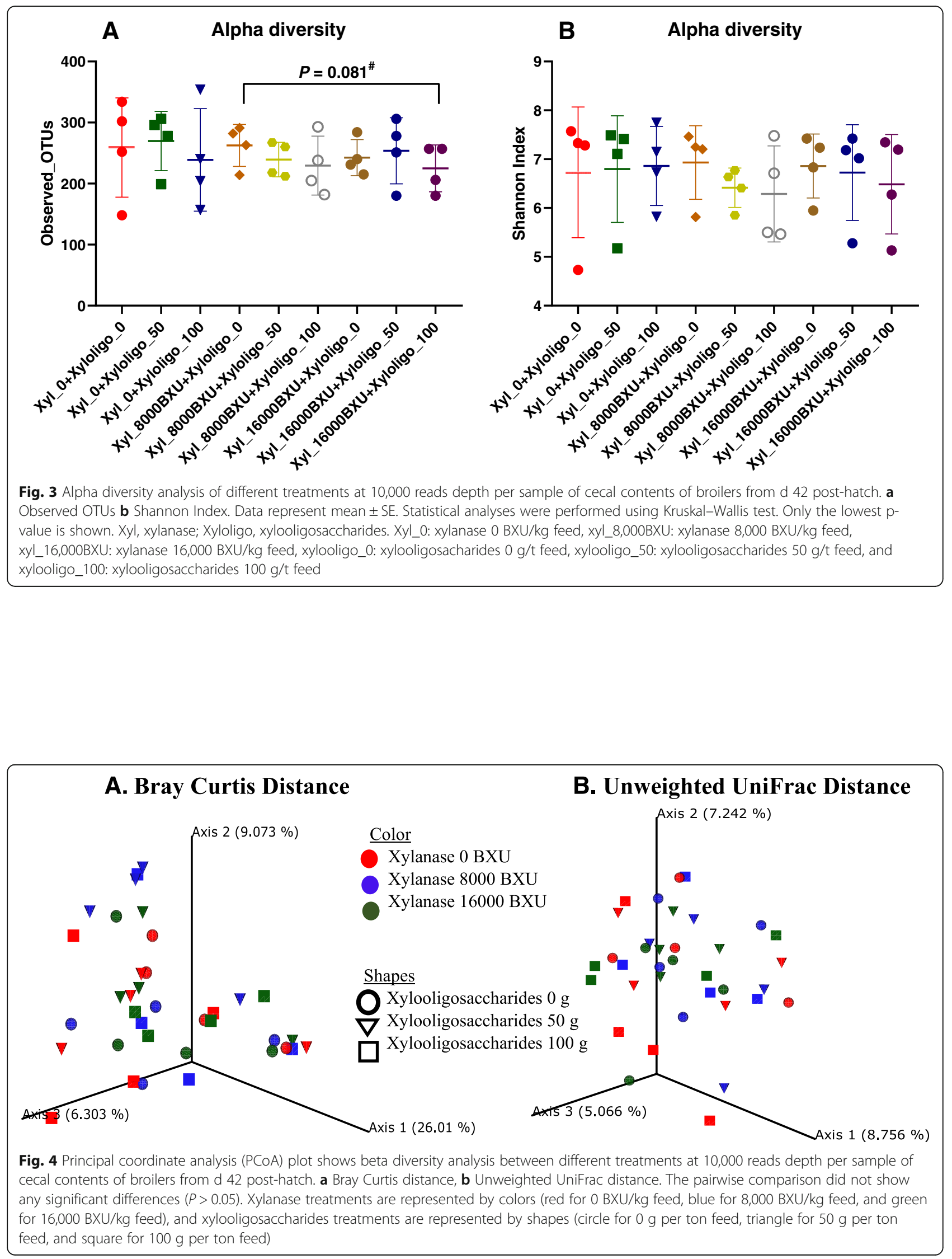


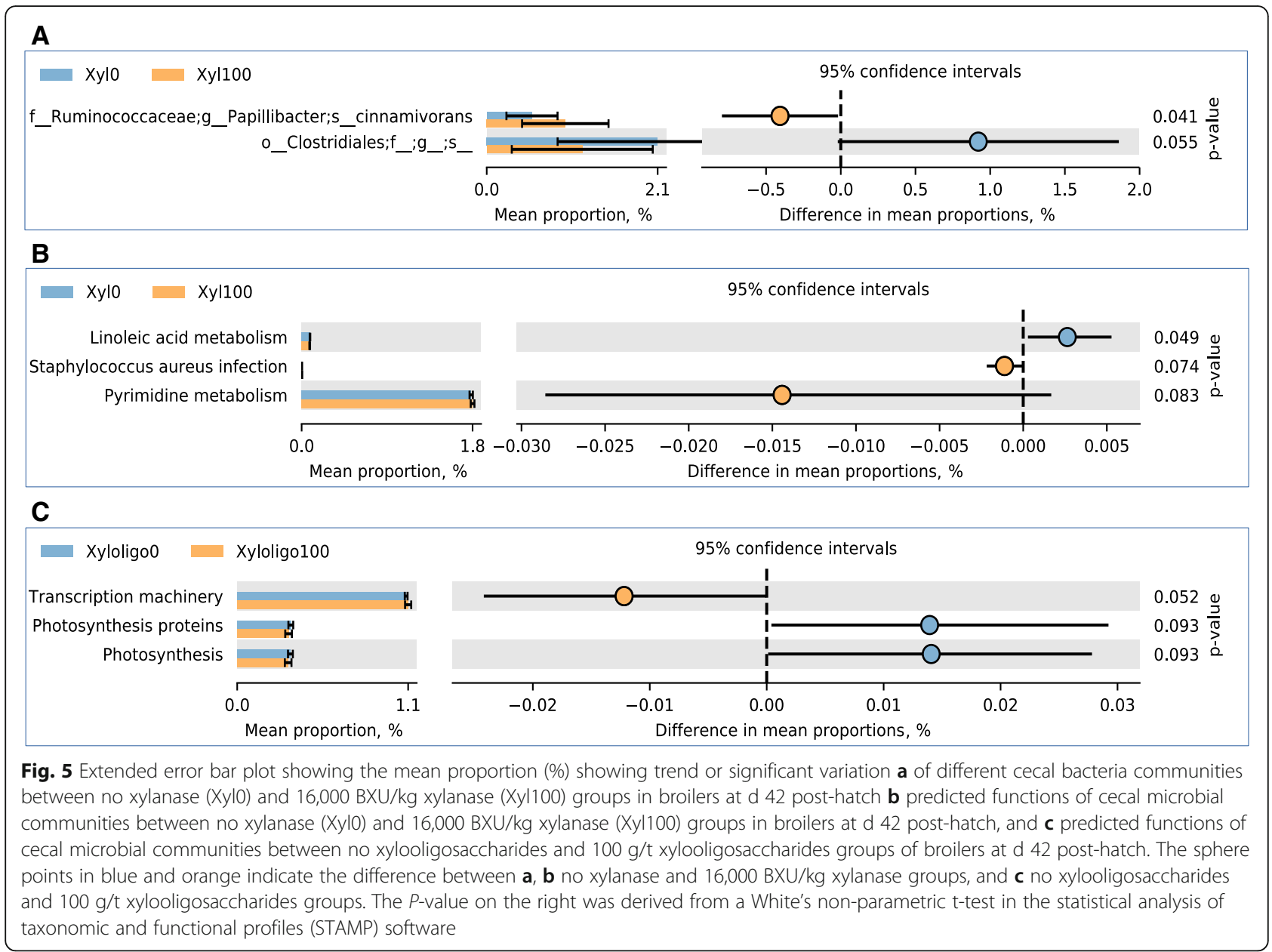

spiroforme and Isobaculum melis $(P<0.05)$. Acetate was correlated positively ( $\rho=0.37$ to 0.4 ) with Papillibacter cinnamivorans, Clostridium lavalense, and Lactobacillus hasmsteri and negatively $(\rho=-0.39)$ with Bacteroides acidifaciens $(P<$ 0.05 ). Propionate was correlated negatively ( $\rho=-0.35$ to 0.40) with Papillibacter cinnamivorans, Clostridium methylpentosum and Ruminococcus lactaris $(P<0.05)$.

\section{Discussion}

The supplementation of xylanase can improve AME and amino acid digestibility in a wheat-based diet [26], which can subsequently improve the broiler's growth performance [13]. The exogenous xylanase has also been reported to improve the nutrient digestibility and growth performance in broilers fed corn-based diets [27, 28]. However, the amount of insoluble and soluble NSP present in the digesta and the type of xylanase included in the diet could affect the broilers' performance [29]. The role of xylanase in improving nutrient utilization in broilers is substantiated by the observed linear improvement in ADG in the finisher and ADG and FBWG in the total period. A similar improvement in the ADG and the final body weight gain by exogenous xylanase was observed in a recent study by Singh et al. [4]. The authors also reported an interaction between additional dietary fiber source and xylanase for FCR, indicating no additional improvement in FCR by xylanase in cornSBM diet, and this observation is in line with the findings of the present study. It was also observed that 8,000 $\mathrm{BXU} / \mathrm{kg}$ xylanase generated a comparable improvement in broilers' performance as $16,000 \mathrm{BXU} / \mathrm{kg}$ supplementation. It suggests that this level of xylanase inclusion can degrade the pentosans substrates at a standard fiber content in the broilers feed. Hence it necessitates that the effects of the higher doses of xylanase be evaluated at different increasing levels of dietary fiber as several authors have reported that increasing the level of xylanase in the feed than recommended did not yield further improvements, while in some studies it reduced the growth and nutrients digestibility in broilers $[8,27,30]$. In this study, XOS supplementation produced only a numerical improvement in FBWG and ADG in the total period compared with groups without XOS supplementation. In contrast, XOS has been reported to increase body 


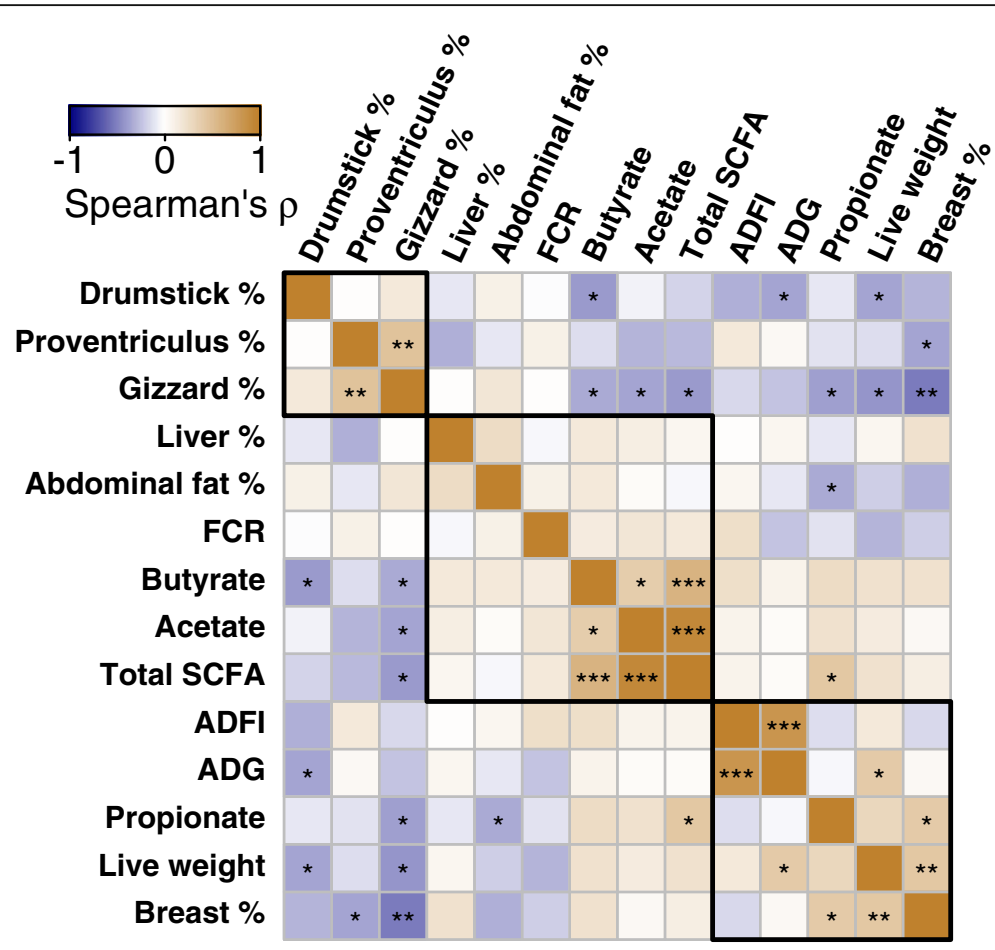

Fig. 6 A correlogram showing association among metabolic functions, growth performance parameters, and carcass weight variables across all treatments in broilers at d 42 post-hatch. The spearman's rho $(\rho)$ correlation coefficient is denoted by the color of the heatmap, and the values are represented in the legend, where the blue color denotes negative correlation while the brown color denotes positive correlation. The asterisk in the cell represents a statistically significant correlation ( $\left.{ }^{*} P \leq 0.05,{ }^{* *} P \leq 0.01,{ }^{* *} P \leq 0.001\right)$, and the rectangles with a black border indicate clustering of the parameters. The percentage (\%) organ weight denotes the relative organ weight ( $\mathrm{g} / 100 \mathrm{~g}$ live weight). ADFl: average daily feed intake, ADG: average daily gain, FCR: feed conversion ratio. Live weight $=$ Total body weight at $\mathrm{d} 42$

weight gain in broilers in the study of Zhenping et al. [17]. The differences in the outcomes could be attributed to the variability in the extraction of XOS and a 10 times higher level of XOS used in the study of Zhenping et al. [17] compared with the lower level used in the present study. The supplemental xylanase only had a trend for the increment of $\mathrm{VH}$ : $\mathrm{CD}$ ratio in the ileum, while XOS did not influence this ratio. The addition of oligosaccharides has also not been found to affect this ratio by Shang et al. [31], while due to the lack of high viscosity in corn-SBM-based diet, the effect of xylanase on this ratio may not have been significantly larger [32].

It is interesting to observe that both XOS and xylanase increased the production of acetate in the ceca, and it indicates their influence in modulating the fermentation characteristics of cecal microbiota. The XOS in this study was supplemented in low concentration that is not expected to produce sufficient SCFA, but the substantial increase in SCFA in response to XOS could be attributed to its priming of cecal microbiota for enhanced fermentation of selective substrates [1]. Recently, a term "stimbiotic" has been proposed to suggest the mechanism by which the oligosaccharides could influence the utilization of similar nutrients and their extraction from the diet by the gut microbiota [33]. It has been interpreted that while these oligosaccharides supplied in the diet or generated in situ in a small quantity are insufficient to contribute to a differentially high amount of SCFA production in the ceca of broilers, but it acts as a signaling molecule that stimulates the microbial adaptation to degrade dietary fiber sources [1]. Moreover, a similar effect of xylanase on the increase of acetate and total SCFA was also reported by Dale et al. [9] and Singh et al. [4]. In a previous study in laying hens, Ding et al. [15] found that XOS has an immunomodulating effect and the increase in IL-4 and IL-10 cytokines in the high XOS group in the present study also supports this observation. However, whether it is a direct effect of XOS or an indirect influence through the metabolites produced by the gut microbiota utilizing XOS substrates remains unexplained. The XOS administration in a mice study has been reported to reduce IL- $1 \beta$ level in the blood, but it did not affect any immune-related genes in the intestine and thus indicates the variability in the immune system's response in different body sites and tissues [34]. The positive correlation of propionate with the relative weight of the breast suggests that this glucogenic SCFA would be an important contributor to breast muscle 


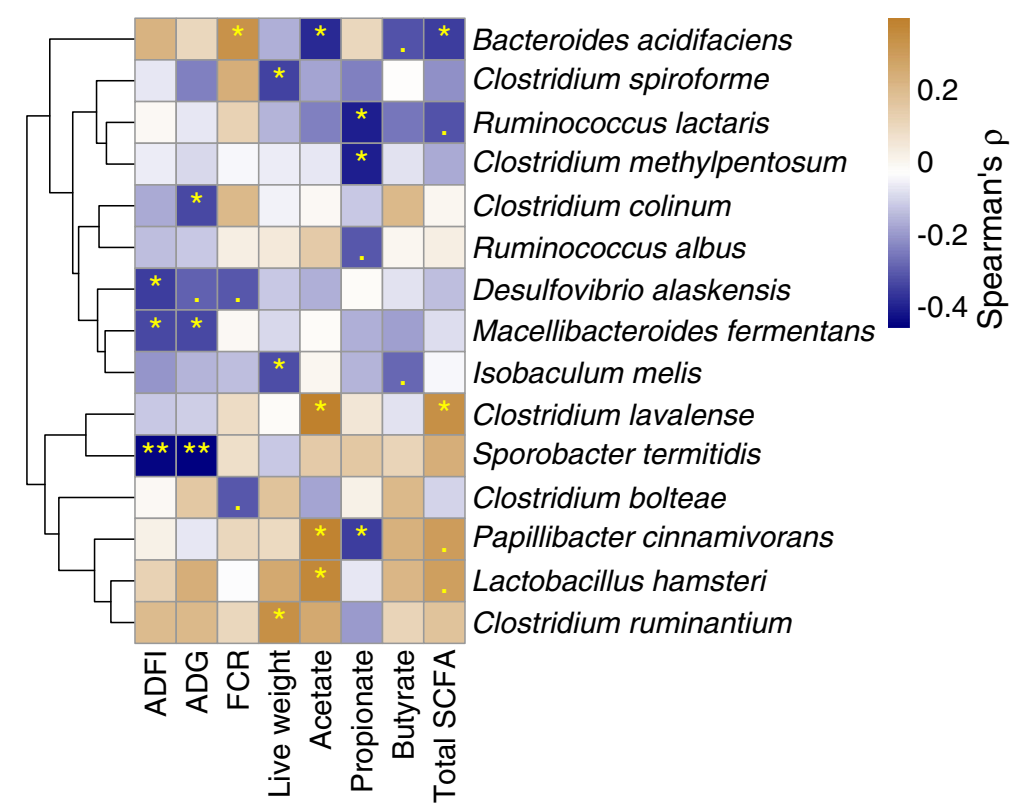

Bacteroides acidifaciens Clostridium spiroforme Ruminococcus lactaris Clostridium methylpentosum Clostridium colinum Ruminococcus albus Desulfovibrio alaskensis Isobaculum melis Clostridium lavalense Sporobacter termitidis Clostridium bolteae

actobacillus hamster

Fig. 7 A heatmap showing an association between some cecal bacterial species and biological parameters across all treatments in broilers at $d$ 42 post-hatch. The Spearman's rho $(\rho)$ correlation coefficient is denoted by the color of the heatmap, and the values are represented in the legend, where the blue color denotes negative correlation while the brown color denotes positive correlation. The yellow asterisks in the cell indicate a statistically significant correlation $\left({ }^{*} P \leq 0.05,{ }^{* *} P \leq 0.01\right)$, while the dots indicate approaching significance or a trend $(P<0.1)$. The dendrogram is generated by the Euclidean distance method and represents the clustering of bacterial species. ADFl: average daily feed intake, ADG: average daily gain, FCR: feed conversion ratio. Live weight $=$ Total body weight at $\mathrm{d} 42$

growth [35, 36]. The negative correlation of relative gizzard weight with the production of SCFA suggests that a reduced grinding force would provide more undigested substrates for bacterial fermentation in the ceca of broilers [37]. The abundance of Firmicutes phylum was above $75 \%$ across all treatments, and it is in agreement with that observed by Zhang et al. [38]. In broilers fed corn hulls derived XOS, Samanta et al. [39] reported that XOS reduced the population of E. coli and Streptococci, and stimulated the increase of Bifidobacteria. However, in the present study, such a considerable impact on these microbiotas was not observed in response to either xylanase or XOS. The addition of xylanase increased the Papillibacter cinnamivorans bacteria of the family Ruminococcaceae, and the bacteria in this family are known to support the host by producing enzymes to degrade and utilize fiber $[40,41]$. The $P$. cinnamivorans can utilize cinnamate, a precursor of lignin, to produce acetate and show a ligninolytic activity $[42,43]$. The positive correlation between $P$. cinnamivorans and acetate also supports this underlying mechanism of the utilization of substrates to produce acetate. The positive correlation of acetate production with Lactobacillus observed in this study was also reported previously [44], and acetate has been found to be produced from lactate when the glucose resource gets depleted [45]. The positive correlation of Bacteroides acidifaciens with FCR and its negative correlation with acetate suggests that the gut microbiome plays roles beyond fermentation and support growth and lipid utilization [46, 47]. In the present study, the scale of the response of xylanase was greater than that of XOS on cecal microbiota and its fermentative production of SCFA. Nonetheless, the lack of significant interaction between xylanase and XOS points to their working by the additive mechanism. However, further studies are warranted to elucidate such variable response of cecal microbiota to the supplementation of xylanase and XOS, and their interaction in broilers.

\section{Conclusions}

The results of this study support the hypothesis that the xylanase supplementation in the corn-SBM-based diet is capable of improving the growth performance in broilers. Moreover, it can be inferred from the results that xylanase and XOS supplementation in the broilers diet can potentially enhance the production of SCFA through increased cecal fermentation. However, such improvements may not necessarily depend on the shift in the microbiota diversity or the enhancement of mucosal absorptive surface. The numerical improvements in the bodyweight by XOS were evident, but it failed to reach statistical significance in the present study, and thus it is recommended that more birds be used in future studies of XOS supplementation in broilers. 


\section{Supplementary Information}

The online version contains supplementary material available at https://doi. org/10.1186/s40104-021-00617-8.

Additional file 1. Table S1. Spearman correlation between metabolic functions, growth performance parameters, and carcass weight variables across all treatments inbroilers at d 42 post-hatch. Table S2. Spearman correlation between the differential bacterial species and biological parameters across all treatments in broilers at $\mathrm{d} 42$ post-hatch.

\section{Acknowledgements}

None.

\section{Authors' contributions}

AKS, MB, RJ conceptualized and designed the study; AKS conducted animal experiment, analyzed data, and drafted original manuscript; BM, MB, RJ reviewed and provided critical comments on the manuscript. The authors read and approved the final manuscript.

\section{Funding}

This study was supported by AB Vista Feed Ingredients, Marlborough, Wiltshire, UK.

\section{Availability of data and materials} Not applicable.

\section{Declarations}

\section{Ethics approval and consent to participate}

All the animal experimentation was carried out following the guidelines approved by the Institutional Animal Care and Use Committee of the University of Hawaii.

\section{Consent for publication}

Not applicable.

\section{Competing interests}

The authors declare that there is no conflict of interest.

\section{Author details}

'Department of Human Nutrition, Food and Animal Sciences, University of Hawaii at Manoa, Honolulu, HI 96822, USA. ${ }^{2}$ AB Vista Feed Ingredients, Marlborough, Wiltshire, UK

Received: 9 March 2021 Accepted: 1 July 2021

Published online: 06 September 2021

\section{References}

1. Bedford MR. The evolution and application of enzymes in the animal feed industry: the role of data interpretation. Br Poult Sci. 2018;59(5):486-93.

2. $\quad$ Singh AK, Berrocoso JD, Dersjant-Li Y, Awati A, Jha R. Effect of a combination of xylanase, amylase and protease on growth performance of broilers fed low and high fiber diets. Anim Feed Sci Technol. 2017;232:1620

3. Singh AK, Tiwari UP, Berrocoso JD, Dersjant-Li Y, Awati A, Jha R. Effects of a combination of xylanase, amylase and protease, and probiotics on major nutrients including amino acids and non-starch polysaccharides utilization in broilers fed different level of fibers. Poult Sci. 2019:98(11):5571-81.

4. Singh AK, Mandal RK, Bedford MR, Jha R. Xylanase improves growth performance, enhances cecal short chain fatty acids production, and increases the relative abundance of fiber fermenting cecal microbiota in broilers. Anim Feed Sci Technol 2021:114956.

5. Jha R, Fouhse JM, Tiwari UP, Li L, Willing BP. Dietary fiber and intestinal health of monogastric animals. Front Vet Sci. 2019;6:48.

6. Tiwari UP, Chen H, Kim SW, Jha R. Supplemental effect of xylanase and mannanase on nutrient digestibility and gut health of nursery pigs studied using both in vivo and in vitro models. Anim Feed Sci Technol. 2018;245: 77-90.

7. Biely $P$, Vršanská $M$, Tenkanen M, Kluepfel $D$. Endo- $\beta-1$, 4-xylanase families: differences in catalytic properties. J Biotechnol. 1997;57(1-3):151-66.
8. Masey-O'Neill HV, Singh M, Cowieson AJ. Effects of exogenous xylanase on performance, nutrient digestibility, volatile fatty acid production and digestive tract thermal profiles of broilers fed on wheat-or maize-based diet. Br Poult Sci. 2014:55(3):351-9.

9. Dale T, Hannay I, Bedford MR, Tucker GA, Brameld JM, Parr T. The effects of exogenous xylanase supplementation on the in vivo generation of xylooligosaccharides and monosaccharides in broilers fed a wheat-based diet. Br Poult Sci. 2020;61(4):471-81.

10. Choct M, Hughes RJ, Wang J, Bedford MR, Morgan AJ, Annison G. Increased small intestinal fermentation is partly responsible for the anti-nutritive activity of non-starch polysaccharides in chickens. Br Poult Sci. 1996;37(3): 609-21

11. Courtin CM, Broekaert WF, Swennen K, Lescroart O, Onagbesan O, Buyse J, et al. Dietary inclusion of wheat bran arabinoxylooligosaccharides induces beneficial nutritional effects in chickens. Cereal Chem. 2008:85(5):607-13.

12. Vahjen W, Gläser K, Schäfer K, Simon O. Influence of xylanase-supplemented feed on the development of selected bacterial groups in the intestinal tract of broiler chicks. J Agric Sci. 1998;130(4):489-500.

13. Singh AK, Kim WK. Effects of dietary fiber on nutrients utilization and gut health of poultry: a review of challenges and opportunities. Animals. 2021; 11:181.

14. De Maesschalck C, Eeckhaut V, Maertens L, De Lange L, Marchal L, Nezer C, et al. Effects of xylo-oligosaccharides on broiler chicken performance and microbiota. Appl Environ Microbiol. 2015;81(17):5880-8.

15. Ding XM, Li DD, Bai SP, Wang JP, Zeng QF, Su ZW, et al. Effect of dietary xylooligosaccharides on intestinal characteristics, gut microbiota, cecal short-chain fatty acids, and plasma immune parameters of laying hens. Poult Sci. 2018:97(3):874-81.

16. Morgan NK, Keerqin C, Wallace A, Wu S-B, Choct M. Effect of arabinoxylooligosaccharides and arabinoxylans on net energy and nutrient utilization in broilers. Anim Nutr. 2019;5(1):56-62.

17. Zhenping $S$, Wenting $L$, Ruikui $Y$, Jia $L$, Honghong $L$, Wei $S$, et al. Effect of a straw-derived xylooligosaccharide on broiler growth performance, endocrine metabolism, and immune response. Can J Vet Res. 2013;77(2): 105-9.

18. NRC. Nutrient Requirements of Poultry, 9th revised edn. National Academy Press, Washington DC, USA: National Research Council; 1994.

19. AOAC. Official Methods of Analysis, 18th edn. Arlington, VA: Association of Official Analytical Chemists; 2006.

20. Wasti S, Sah N, Singh AK, Lee CN, Jha R, Mishra B. Dietary supplementation of dried plum: a novel strategy to mitigate heat stress in broiler chickens. J Animal Sci Biotechnol. 2021;12(1):1-17.

21. Berrocoso JD, Kida R, Singh AK, Kim YS, Jha R. Effect of in ovo injection of raffinose on growth performance and gut health parameters of broiler chicken. Poult Sci. 2017:96(6):1573-80.

22. Klindworth A, Pruesse E, Schweer T, Peplies J, Quast C, Horn M, et al. Evaluation of general $16 \mathrm{~S}$ ribosomal RNA gene PCR primers for classical and next-generation sequencing-based diversity studies. Nucleic Acids Res. 2013; 41(1):e1.

23. Bolyen E, Rideout JR, Dillon MR, Bokulich NA, Abnet CC, Al-Ghalith GA, et al. Reproducible, interactive, scalable and extensible microbiome data science using QIIME 2. Nat Biotechnol. 2019;37(8):852-7.

24. Parks DH, Tyson GW, Hugenholtz P, Beiko RG. STAMP: statistical analysis of taxonomic and functional profiles. Bioinformatics. 2014;30(21):3123-4.

25. White JR, Nagarajan N, Pop M. Statistical methods for detecting differentially abundant features in clinical metagenomic samples. PLoS Comput Biol. 2009;5(4):e1000352.

26. Hew LI, Ravindran V, Mollah Y, Bryden WL. Influence of exogenous xylanase supplementation on apparent metabolisable energy and amino acid digestibility in wheat for broiler chickens. Anim Feed Sci Technol. 1998; 75(2):83-92.

27. Cowieson AJ, Bedford MR, Ravindran V. Interactions between xylanase and glucanase in maize-soy-based diets for broilers. Br Poult Sci. 2010;51(2):246-57.

28. Kiarie $\mathrm{E}$, Romero LF, Ravindran V. Growth performance, nutrient utilization, and digesta characteristics in broiler chickens fed corn or wheat diets without or with supplemental xylanase. Poult Sci. 2014;93(5):1186-96.

29. Choct M, Kocher A, Waters DLE, Pettersson D, Ross G. A comparison of three xylanases on the nutritive value of two wheats for broiler chickens. $\mathrm{Br}$ J Nutr. 2004;92(1):53-61.

30. Pourreza J, Classen HL. Effects of supplemental phytase and xylanase on phytate phosphorus degradation, ileal protein and energy digestibility of a 
corn-soybean-wheat bran diets in broiler chicks. J Agric Sci Technol. 2001; 3(1):19-25.

31. Shang Y, Regassa A, Kim JH, Kim WK. The effect of dietary fructooligosaccharide supplementation on growth performance, intestinal morphology, and immune responses in broiler chickens challenged with Salmonella Enteritidis lipopolysaccharides. Poult Sci. 2015;94(12):2887-97.

32. Jiménez-Moreno E, Frikha M, de Coca-Sinova A, Lázaro RP, Mateos GG. Oat hulls and sugar beet pulp in diets for broilers. 2. Effects on the development of the gastrointestinal tract and on the structure of the jejunal mucosa. Anim Feed Sci Technol. 2013;182(1-4):44-52.

33. Cho HM, González-Ortiz G, Melo-Durán D, Heo JM, Cordero G, Bedford MR et al. Stimbiotic supplementation improved performance and reduced inflammatory response via stimulating fiber fermenting microbiome in weaner pigs housed in a poor sanitary environment and fed an antibioticfree low zinc oxide diet. PLoS ONE. 2020:15(11):e0240264.

34. Hansen CHF, Frøkiær H, Christensen AG, Bergström A, Licht TR, Hansen AK, et al. Dietary xylooligosaccharide downregulates IFN- $y$ and the low-grade inflammatory cytokine IL-1 $\beta$ systemically in mice. J Nutr. 2013;143(4):533-40.

35. Aschenbach JR, Kristensen NB, Donkin SS, Hammon HM, Penner GB. Gluconeogenesis in dairy cows: the secret of making sweet milk from sour dough. IUBMB Life. 2010;62(12):869-77.

36. Tirosh A, Calay ES, Tuncman G, Claiborn KC, Inouye KE, Eguchi K, et al. The short-chain fatty acid propionate increases glucagon and FABP4 production, impairing insulin action in mice and humans. Sci Transl Med. 2019;11(489): eaav0120.

37. Hetland $\mathrm{H}$, Choct $\mathrm{M}$, Svihus B. Role of insoluble non-starch polysaccharides in poultry nutrition. Worlds Poult Sci J. 2004;60(4):415-22.

38. Zhang Y, Liu Y, Li J, Xing T, Jiang Y, Zhang L, et al. Dietary corn-resistant starch suppresses broiler abdominal fat deposition associated with the reduced cecal Firmicutes. Poult Sci. 2020;99(11):5827-37.

39. Samanta AK, Kotte AP, Elangovan AV, Dhali A, Senani S, Sridhar M, et al. Effects of corn husks derived xylo-oligosaccharides on performance of broiler chicken. Indian J Anim Sci. 2017;87:640-3.

40. Duncan $\mathrm{SH}$, Louis $\mathrm{P}$, Flint $\mathrm{HJ}$. Cultivable bacterial diversity from the human colon. Lett Appl Microbiol. 2007:44(4):343-50.

41. Jha R, Mishra P. Dietary fiber in poultry nutrition and their effects on nutrient utilization, performance, gut health, and on the environment: a review. J Anim Sci Biotechnol. 2021;12:51.

42. Defnoun S, Labat M, Ambrosio M, Garcia J-L, Patel BK. Papillibacter cinnamivorans gen. nov., sp. nov., a cinnamate-transforming bacterium from a shea cake digester. Int J Syst Evol Microbiol. 2000;50(3):1221-8.

43. Peng X, Misawa N, Harayama S. Isolation and characterization of thermophilic bacilli degrading cinnamic, 4-coumaric, and ferulic acids. Appl Environ Microbiol. 2003;69(3):1417-27.

44. Liao X, Shao Y, Sun G, Yang Y, Zhang L, Guo Y, et al. The relationship among gut microbiota, short-chain fatty acids, and intestinal morphology of growing and healthy broilers. Poult Sci. 2020;99(11):5883-95.

45. Goffin P, Muscariello L, Lorquet F, Stukkens A, Prozzi D, Sacco M, et al. Involvement of pyruvate oxidase activity and acetate production in the survival of Lactobacillus plantarum during the stationary phase of aerobic growth. Appl Environ Microbiol. 2006;72(12):7933-40.

46. Yang JY, Lee YS, Kim Y, Lee SH, Ryu S, Fukuda S, et al. Gut commensal Bacteroides acidifaciens prevents obesity and improves insulin sensitivity in mice. Mucosal Immunol. 2017;10(1):104-16.

47. Yadav $S$, Jha R. Strategies to modulate the intestinal microbiota and their effects on nutrient utilization, performance, and health of poultry. J Anim Sci Biotechnol. 2019;10:2.

Ready to submit your research? Choose BMC and benefit from:

- fast, convenient online submission

- thorough peer review by experienced researchers in your field

- rapid publication on acceptance

- support for research data, including large and complex data types

- gold Open Access which fosters wider collaboration and increased citations

- maximum visibility for your research: over $100 \mathrm{M}$ website views per year

At BMC, research is always in progress.

Learn more biomedcentral.com/submissions 